\title{
Microwave Synthesis of Arylmethyl Substituted Pyrazoles
}

\author{
Consuelo Escolástico*,a ${ }^{*}$, Mercedes Blanco ${ }^{\mathrm{b}}$, Rosa M. Claramunt ${ }^{\mathrm{a}}$, Dionisia Sanz ${ }^{*, \mathrm{a}}$ and \\ José Elguero ${ }^{\mathrm{c}}$
}

\author{
${ }^{a}$ Departamento de Química Orgánica y Bio-Orgánica, Facultad de Ciencias, UNED, Senda del Rey 9, E-28040 Madrid, \\ Spain \\ ${ }^{b}$ On leave from the Departamento de Química Orgánica, Facultad de Farmacia y Bioquímica, Universidad de Buenos \\ Aires, Junín 956 (1113) Buenos Aires, Argentina \\ "Instituto de Química Médica, Centro de Química Orgánica "Manuel Lora Tamayo", CSIC, Juan de la Cierva 3, E- \\ 28006 Madrid, Spain
}

\begin{abstract}
The synthesis under MW irradiation without solvent of 19 pyrazoles, of which only 8 were known, is described. They bear $C$-methyl groups and trityl, diphenylmethyl and benzyl groups at positions 1 and 4 of the pyrazole ring. In the reaction between pyrazole and trityl bromide an unexpected reaction occurred and 4-(9-phenyl-9H-fluoren-9-yl)- $1 H$ pyrazole (7) was isolated.
\end{abstract}

Keywords: Microwave, pyrazoles, tritylpyrazole, fluorenylpyrazole, oxidation.

\section{To Professor Alain Fruchier from the Ecole Nationale Superieure de Chimie of Montpellier (France) on the occasion of his retirement.}

\section{INTRODUCTION}

Substituted pyrazoles present a wide range of biological activities: they can be used as inhibitors and deactivators of liver alcohol dehydrogenase, antitumor, antiviral or antimicrobial agents, anti-inflammatory or antifungal drugs [1,2]. After these reviews appeared, many other pyrazoles possessing biological properties have been described, too numerous to be reported here. Since, in principle, the fate of these active molecules is to evolve progressively to attain the status of drugs, it is important to devise clean systems of preparation. For this reason, we have turned our attention to the synthesis of $N$ - and $C$-substituted derivatives by alkylation of $N$ unsubstituted pyrazoles. Note that direct $C$-alkylation at specific positions of the pyrazole ring is in general a very difficult reaction to carry out [3]. Rimonabant, 5-(4chlorophenyl)-1-(2,4-dichlorophenyl)-4-methyl- $N$-(piperidin1-yl)-1H-pyrazole-3-carboxamide, the first selective CB1 blocker to be approved for use anywhere in the world is a 4methylpyrazole derivative [1], and a 2005 patent reports the use of 1-diphenylmethylpyrazole derivatives as opioid receptor ligands [4].

Microwave irradiation (MW) activation has been often used in pyrazole chemistry, but seldom for $\mathrm{N}$-/C-substitution. Some examples are the $C$-adamantylation of pyrazoles [5-7], and the use of MW for the $N$-alkylation of pyrazoles [8]. In the present work, we have performed the alkylation reaction of $1 H$-pyrazole (1), 3(5)-methyl- $1 H$-pyrazole (2) and 3,5dimethyl-1H-pyrazole (3) (Fig. 1) under MW without solvent aiming to obtain either 4-substituted or 1-substituted

*Address correspondence to these authors at the Departamento de Química Orgánica y Bio-Orgánica, Facultad de Ciencias, UNED, Senda del Rey 9, E28040 Madrid, Spain; Tel: (+34) 913988960 (CE), (+34) 91.398.73.31 (DS); Fax: (+34) 91.398.66.97; E-mails: cescolastico@ccia.uned.es; dsanz@ccia.uned.es derivatives $[5,6]$. Some reaction parameters, such as irradiation power and time and type of halogen derivative have been studied in order to know their influence on the activity and selectivity of the reaction.
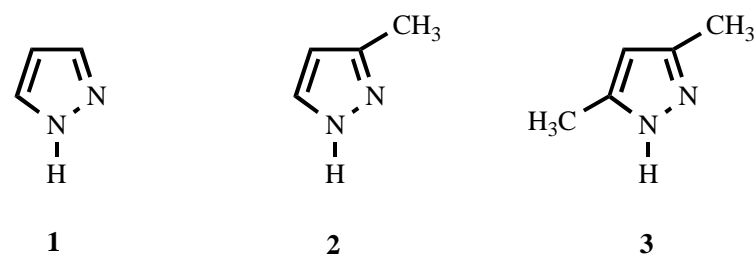

Fig. (1). The starting pyrazoles.

\section{RESULTS AND DISCUSSION}

The alkylation of pyrazoles 1-3 has been carried out with trityl (a series, $\mathrm{R}=\mathrm{Ph}_{3} \mathrm{C}$ ), diphenylmethyl (b series, $\mathrm{R}=$ $\mathrm{Ph}_{2} \mathrm{CH}$, benzhydryl) and benzyl (c series, $\mathrm{R}=\mathrm{PhCH}_{2}$ ) halides (both chlorides and bromides). A mixture of pyrazoles 1-3 and halogen derivatives was placed in an air-open tube; the system was irradiated in a multimode microwave oven at different powers $(600 \mathrm{~W}$ and $900 \mathrm{~W}$, no effect was observed) and times $(3,5$ and $10 \mathrm{~min})$. The reaction occurs in semisolid/liquid state and the activity/selectivity was very similar in spite of different powers and times of irradiation. After cooling to room temperature, the reaction crude was dissolved in dichloromethane and chromatographed over silica gel.

The structures and percentages of the different compounds (see Fig. 2), depicted in Tables 1, $\mathbf{2}$ and 3, have been determined by ${ }^{1} \mathrm{H}$ NMR spectroscopy. Gas chromatography coupled to mass spectrometry (see conditions in the experimental section) present some difficulties due to either long retention times or isomerization processes. For example in the case of $1 H$-pyrazole (1) and trityl halides, the retention 


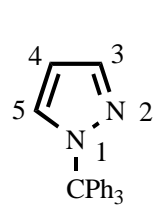

$4 a$

$\mathrm{Ph}_{2} \mathrm{HC}$<smiles>Cc1cn[nH]c1</smiles>

$6 b$<smiles>Cc1nn(C(c2ccccc2)c2ccccc2)cc1C(c1ccccc1)c1ccccc1</smiles>

$10 b$

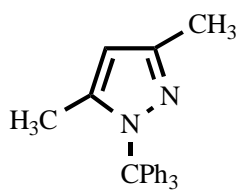

$12 \mathrm{a}$

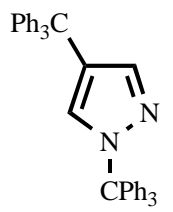

$\mathrm{Ph}_{3} \mathrm{C}$<smiles>Cc1cn[nH]c1</smiles>

$6 a$<smiles>c1ccc(C2(c3cn[nH]c3)c3ccccc3-c3ccccc32)cc1</smiles>

7<smiles>c1ccc(Cn2cccn2)cc1</smiles>

$4 b$<smiles>Cc1ccn(C(C)(F)c2ccccc2)n1</smiles>

6c

$8 a$

8b

$4 c$<smiles>Cc1ccnn1Cc1ccccc1</smiles><smiles>Cc1n[nH]cc1C(c1ccccc1)c1ccccc1</smiles>

$11 b$<smiles>Cc1ccn(Cc2ccccc2)n1</smiles><smiles>Cc1ccnn1Cc1ccccc1</smiles>

8c

9c<smiles>Cc1cc(C)n(Cc2ccccc2)n1</smiles><smiles>Cc1n[nH]c(C)c1Cc1ccccc1</smiles>

12c<smiles>Cc1n[nH]c(C)c1C(c1ccccc1)c1ccccc1</smiles>

13b

Fig. (2). The 19 synthesized pyrazoles.

times for the reaction products were $\mathbf{4 a}, 27.1 \mathrm{~min}, \mathbf{6 a}, 38.2$ and 7 of $45.5 \mathrm{~min}$.

Table 1. Percentages of Compounds Obtained from $1 \mathrm{H}$ pyrazole (1) Under Different Conditions

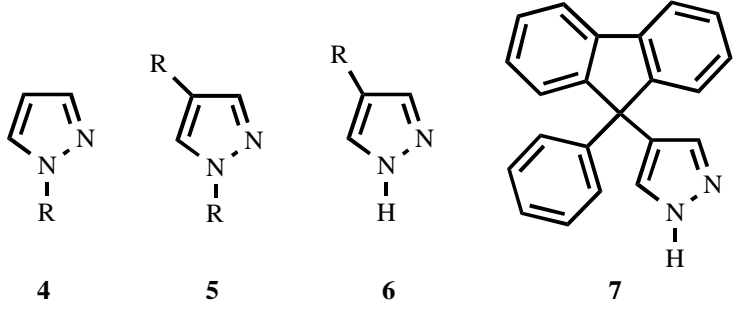

\begin{tabular}{|c|c|c|c|c|}
\hline Alkyl halides & $\mathbf{4}$ & $\mathbf{5}$ & $\mathbf{6}$ & $\mathbf{7}$ \\
\hline \hline $\mathrm{Ph}_{3} \mathrm{CCl}$ & 85 & 15 & --- & --- \\
\hline $\mathrm{Ph}_{3} \mathrm{CBr}$ & --- & --- & 30 & 70 \\
\hline $\mathrm{Ph}_{2} \mathrm{CHCl}$ & 100 & --- & --- & --- \\
\hline $\mathrm{Ph}_{2} \mathrm{CHBr}$ & --- & --- & 100 & --- \\
\hline $\mathrm{PhCH}_{2} \mathrm{Cl}$ & 100 & & & \\
\hline $\mathrm{PhCH}_{2} \mathrm{Br}$ & 99 & --- & --- & --- \\
\hline
\end{tabular}

Table 2. Percentages of Compounds Obtained from 3(5)methyl-1H-pyrazole (2) Under Different Conditions
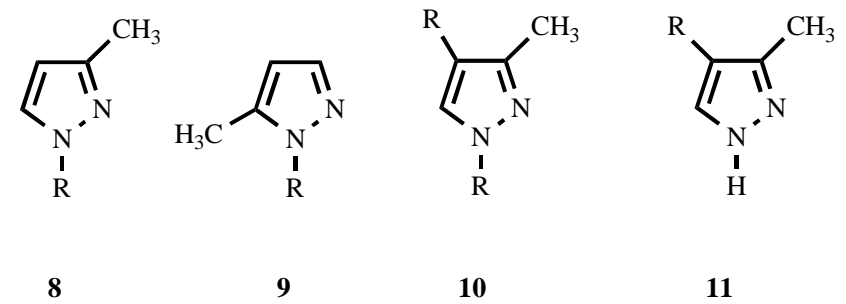

\begin{tabular}{|c|c|c|c|c|}
\hline Alkyl halides & $\mathbf{8}$ & $\mathbf{9}$ & $\mathbf{1 0}$ & $\mathbf{1 1}$ \\
\hline $\mathrm{Ph}_{3} \mathrm{CCl}$ & 100 & --- & --- & --- \\
\hline $\mathrm{Ph}_{3} \mathrm{CBr}$ & --- & --- & --- & --- \\
\hline $\mathrm{Ph}_{2} \mathrm{CHCl}$ & 43.5 & 11 & 18 & 27.5 \\
\hline $\mathrm{Ph}_{2} \mathrm{CHBr}$ & --- & --- & --- & 100 \\
\hline $\mathrm{PhCH}_{2} \mathrm{Cl}$ & 65 & 35 & & \\
\hline $\mathrm{PhCH}_{2} \mathrm{Br}$ & 67 & 33 & & \\
\hline
\end{tabular}


Table 3. Percentages of Compounds Obtained from 3,5dimethyl-1H-pyrazole (3) Under Different Conditions

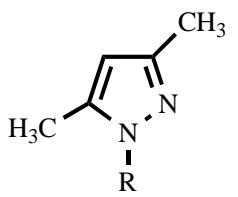

12

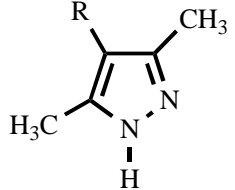

13

\begin{tabular}{|c|c|c|}
\hline Alkyl halides & $\mathbf{1 2}$ & $\mathbf{1 3}$ \\
\hline \hline $\mathrm{Ph}_{3} \mathrm{CCl}$ & 100 & --- \\
\hline $\mathrm{Ph}_{3} \mathrm{CBr}$ & --- & -- \\
\hline $\mathrm{Ph}_{2} \mathrm{CHCl}$ & --- & 100 \\
\hline $\mathrm{Ph}_{2} \mathrm{CHBr}$ & --- & 100 \\
\hline $\mathrm{PhCH}_{2} \mathrm{Cl}$ & 100 & --- \\
\hline $\mathrm{PhCH}_{2} \mathrm{Br}$ & --- & 100 \\
\hline
\end{tabular}

With trityl chloride the $N$-substituted derivative was the main reaction product in all cases. In contrast the reaction of trityl bromide with 3-methyl-1H-pyrazole (2) or 3,5dimethyl-1H-pyrazole (3) afforded only triphenylmethane yielding 4-(9-phenyl-9H-fluoren-9-yl)- $1 H$-pyrazole (7) and 4-trityl-1H-pyrazole (6a) in the case of $1 H$-pyrazole (1).

A mixture of 6a (30\%) and 7 (70\%) was detected by gas chromatography coupled to a mass spectrometer and several crystallization assays from ethyl acetate only allowed to get mixtures in variable proportions. Finally a small quantity of pure 7 was obtained from benzene and the ${ }^{1} \mathrm{H}-\mathrm{NMR}$ spectra of the isolated 7 as well as that of a 1:1 mixture are depicted in Fig. 3. The separation of both compounds by liquid chromatography could not be achieved as they presented similar $\mathrm{R}_{f} s$ in the usual organic solvents.

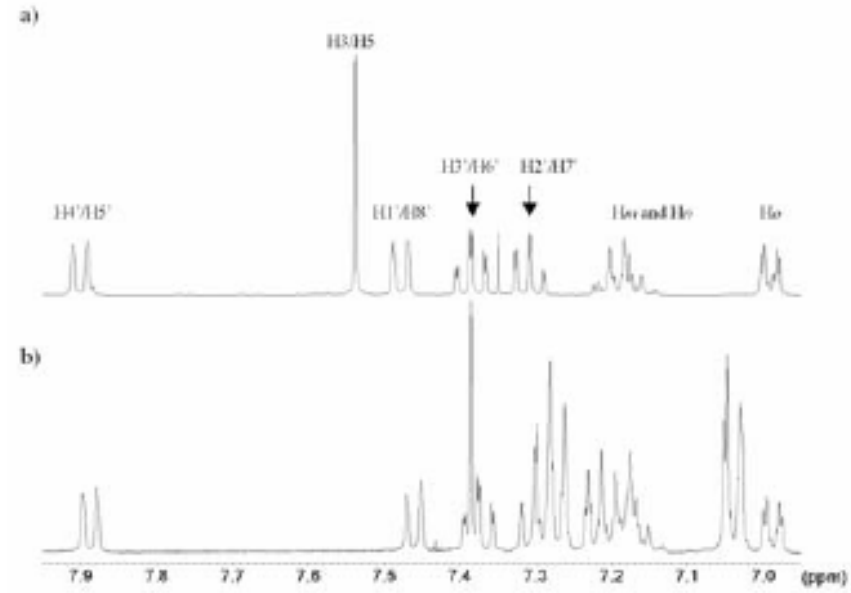

Fig. (3). ${ }^{1} \mathrm{H}-\mathrm{NMR}$ spectra in DMSO- $d_{6}$ of: (a) pure 7; (b) a $1 / 1$ mixture of $6 \mathbf{a}$ and 7.

The structure of 4-(9-phenyl-9H-fluoren-9-yl)- $1 H$ pyrazole (7) was determined by ${ }^{1} \mathrm{H},{ }^{13} \mathrm{C}$ and ${ }^{15} \mathrm{~N}-\mathrm{NMR}$ and the most relevant features will be discussed as follows. In the spectra of Fig. 3a, the multiplicity of the signals (due to the $C_{S}$ symmetry of the fluorene derivative (7), 8 signals in ${ }^{1} \mathrm{H}$ NMR and 14 signals in ${ }^{13} \mathrm{C}$-NMR are expected), the integral and the $\left({ }^{1} \mathrm{H}-{ }^{1} \mathrm{H}\right)$ gs-COSY correlation established the protons sequence to be: H4'/H5': $7.90(\mathrm{~d}, 2 \mathrm{H}) \leftrightarrow \mathrm{H}^{\prime} / \mathrm{H} 6$ ' : 7.38 (t, $2 \mathrm{H}) \leftrightarrow \mathrm{H}^{\prime} / \mathrm{H} 7^{\prime}: 7.31(\mathrm{t}, 2 \mathrm{H}) \leftrightarrow \mathrm{H} 1^{\prime} / \mathrm{H} 8^{\prime}: 7.48(\mathrm{~d}, 2 \mathrm{H})$ and $\mathrm{Ho}: 6.99(\mathrm{~m}, 2 \mathrm{H}) \leftrightarrow \mathrm{H} m$ and $\mathrm{H} p:$ 7.22-7.16 (m, 3H). From such correlations it was inferred that the structure of 7 contains a 4 -substituted- $1 H$-pyrazole in which the singlet at 7.54 ppm corresponds to $\mathrm{H} 3 / \mathrm{H} 5$, a $\mathrm{Ph}$ group and two equivalent $\mathrm{C}_{6} \mathrm{H}_{4^{-}}$moieties. From $\left({ }^{1} \mathrm{H}^{-13} \mathrm{C}\right)$ gs-HMQC and gs-HMBC correlations the final structure for $\mathbf{7}$ was corroborated (Table 4). The fluorene substructure presents similar chemical shifts to those encountered for fluorene itself [9].

Compound 7 corresponds to the oxidation of $\mathbf{6 a}$. This formation of a CC bond between two aromatic rings without oxidant or catalyst is very uncommon. Note that we have only found a similar reaction in a communication by Powers et al. not yet the object of a scientific paper, [10] describing the formation of fluorenes from triphenylmethanes. In Fig. $\mathbf{4}$ we have represented the geometry corresponding to the minima calculated using a B3LYP/631G** computational approach: absolute energy, -957.4927 hartrees, ZPE, $842.8 \mathrm{~kJ}$ $\mathrm{mol}^{-1}$, dipole moment, 2.08 Debyes. The most representative dihedral angles have the following values: $\mathrm{C} 3 \mathrm{C} 4 \mathrm{C} 9{ }^{\prime} \mathrm{C} 8$ ' $\mathrm{a}$, $78.8^{\circ} ; \quad \mathrm{C} 3 \mathrm{C} 4 \mathrm{C} 9 \mathrm{C} 9{ }^{\prime} \mathrm{a}, \quad-171.0^{\circ} ; \quad \mathrm{C} 3 \mathrm{C} 4 \mathrm{C} 9 \mathrm{Ci}, \quad 47.6^{\circ}$; C5C4C9' ${ }^{\prime} 8^{\prime} \mathrm{a}, 95.7^{\circ}$; C5C4C9C9'a, $-14.5^{\circ}$; C5C4C9Ci, $137.9^{\circ}$.

As stated in the experimental part, all derivatives have been fully characterized similarly to compound 7 . When dealing with compounds previously described, appropriate literature data are given. Most particularly, ${ }^{13} \mathrm{C}$ and ${ }^{15} \mathrm{~N}$ NMR data have provided to be the most useful to differentiate between $\mathrm{N}$ - and $\mathrm{C}$ - substitution taking into account chemical shifts and coupling constants data described in the literature for related compounds [9,11-13]. For example in 1,4-bis(trityl)- $1 H$-pyrazole (5a) the chemical shifts of $\mathrm{C} i$ and $\mathrm{C}\left(s p^{3}\right)$ are quite different depending if the trityl group is at position $N-1,143.1 \mathrm{ppm}$ and $78.5 \mathrm{ppm}$, or at position $C-4$, $147.0 \mathrm{ppm}$ and $57.9 \mathrm{ppm}$, similarly to what has been described for $\mathbf{4 a}$ and found by us in 4-trityl- $1 H$-pyrazole $(\mathbf{6 a})$, 1-trityl-3-methyl-1H-pyrazole (8a) and 3-methyl-1,4bis(benzhydryl)- $1 H$-pyrazole (10b). To differentiate between regioisomers as in the case of $\mathbf{8 b} / \mathbf{9 b}$ or $\mathbf{8 c / 9 c}$ the criteria of ${ }^{3} J(\mathrm{H} 4, \mathrm{H} 5)>{ }^{3} J(\mathrm{H} 3, \mathrm{H} 4)$ and ${ }^{4} J(\mathrm{Me} 5 \mathrm{H} 4)>{ }^{4} J(\mathrm{Me} 3 \mathrm{H} 4)$ have been applied. Also it has proved to be very useful the correlation found in the $\left({ }^{1} \mathrm{H}-{ }^{15} \mathrm{~N}\right)$ gs-HMBC spectra between $\mathrm{N} 2$ and the methyl at the 3 position, due to the coupling constants values of ${ }^{3} J(\mathrm{Me} 3 \mathrm{~N} 2)>{ }^{3} J(\mathrm{Me} 5 \mathrm{~N} 1)$ [13].

\section{CONCLUSIONS}

The effect of the three kinds of factors $\left(1: \mathrm{PhCH}_{2}\right.$, $\mathrm{Ph}_{2} \mathrm{CH}, \mathrm{Ph}_{3} \mathrm{C} ; 2$ : $\mathrm{Cl}, \mathrm{Br}$; 3: pyrazoles 1, 2, 3) are not independent and cannot be discussed as such. Assuming that the 1,4-derivatives resulted from the 4-alkylation of 1substituted pyrazoles we have elaborated the scheme represented in Fig. 5. The main effects are: Br favors 4- over 1substituted pyrazoles compared with $\mathrm{Cl}, \mathbf{3}$ that favors 4- over 1-substituted pyrazoles compared with $\mathbf{1}$ and $\mathbf{2}$, and $\mathrm{Ph}_{2} \mathrm{CH}$ that produces the same effect compared with $\mathrm{Ph}_{3} \mathrm{C}$ and still 
Table 4. NMR Data, Chemical Shifts $\left(\delta\right.$, ppm) and Coupling Constants $(J, \mathrm{~Hz})$, for Compound 7 in DMSO- $d_{6}$

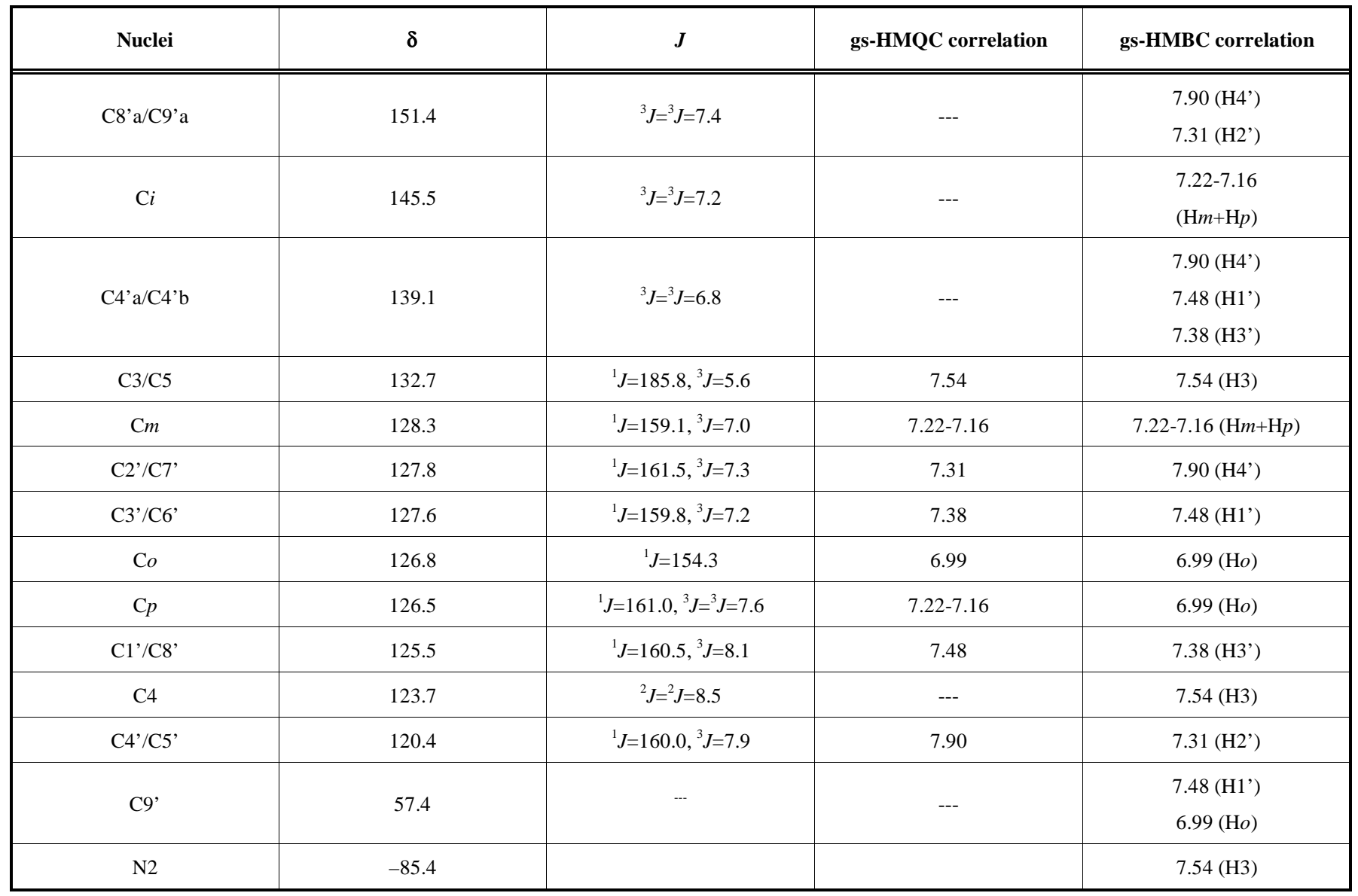

more with $\mathrm{PhCH}_{2}$. The proportion of 3-methyl vs. 5-methyl isomers during $\mathrm{N}$-substitution by $\mathrm{RCl}$ is: $\mathrm{Ph}_{3} \mathrm{C}, 100 \%$ 3-Me; $\mathrm{Ph}_{2} \mathrm{CH}, 80 \%$ 3-Me-20\% 5-Me; $\mathrm{PhCH}_{2}, 65 \%$ 3-Me-35\% 5$\mathrm{Me}$, an obvious steric effect.

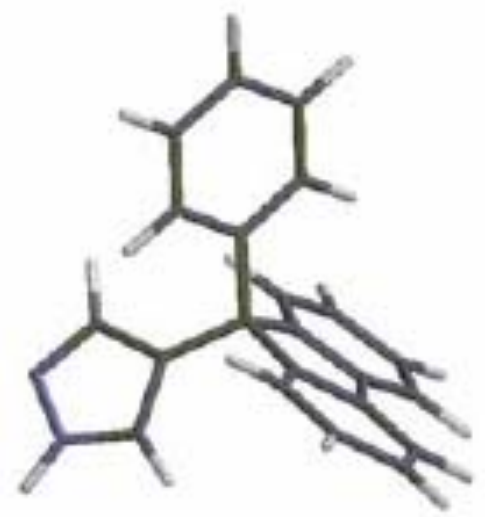

Fig. (4). A view of the 4-(9-phenyl-9H-fluoren-9-yl)- $1 H$-pyrazole (7) equilibrium geometry.

Concerning the synthetic utility of the reactions reported in Tables 1-3 it is clear that several examples have been described to obtain selectively and in high yields $N$-substituted pyrazoles: 4b, 4c, 8a, 12a and 12c. On the other hand, the selective obtention of $C$-substituted derivatives has been achieved in the following cases: $\mathbf{6 b}, \mathbf{1 1 b}, \mathbf{1 3 b}$ and 13c. In all cases microwave irradiation allows pyrazoles alkylation avoiding the use of toxic and flammable organic solvents.

\section{EXPERIMENTAL SECTION}

\section{General Information}

Melting points were determined on a hot-stage microscope and are uncorrected. All products were either compared with known compounds or isolated, purified and identified by melting point, mass spectrometry and NMR spectroscopic data. The $\mathrm{R}_{f}$ values were measured on aluminium backed TLC plates of silica gel 60 F254 (Merck, $0.2 \mathrm{~mm}$ ) with the indicated eluent. Elemental analyses were performed using Perkin-Elmer 240 by "Centro de Microanálisis Elemental-UCM, Madrid". The GC/MS analysis was performed with a Shimadzu GC-17A capillary gas chromatograph (GC) with a CBJ1-M30-025 column, coupled with a Shimadzu QP-5000 mass spectrometer (EI, $60 \mathrm{eV}$ ). The following column temperature programming sequence was an initial temperature of $60{ }^{\circ} \mathrm{C}$ for 5 min increased to $220{ }^{\circ} \mathrm{C}$ at a rate $10{ }^{\circ} \mathrm{C} / \mathrm{min}$ and maintained for $50 \mathrm{~min}$. Helium was used as carrier gas of $2.0 \mathrm{~mL} / \mathrm{min}$ flow rate. Exact mass was determined on a VG AutoSpec Waters spectrometer with the FAB ionization technique using polyethyleneglycol as internal standard. Solution NMR spectra were recorded on a Bruker DRX 400 (9.4 Tesla, $400.13 \mathrm{MHz}$ for ${ }^{1} \mathrm{H}, 100.62$ $\mathrm{MHz}$ for ${ }^{13} \mathrm{C}$ and $40.56 \mathrm{MHz}$ for ${ }^{15} \mathrm{~N}$ ) spectrometer with a 5$\mathrm{mm}$ inverse-detection $\mathrm{H}-\mathrm{X}$ probe equipped with a $\mathrm{z}$-gradient coil, at $300 \mathrm{~K}$. Chemical shifts $(\delta$ in $\mathrm{ppm})$ are given from 


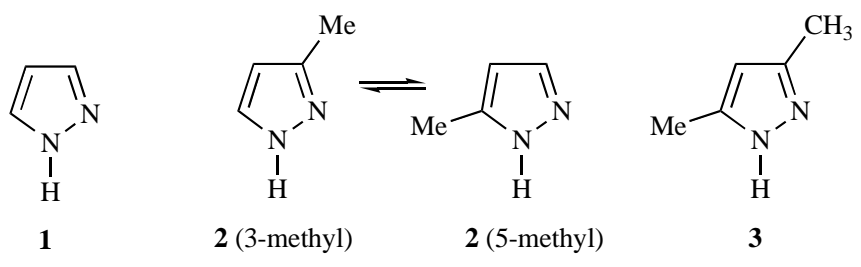

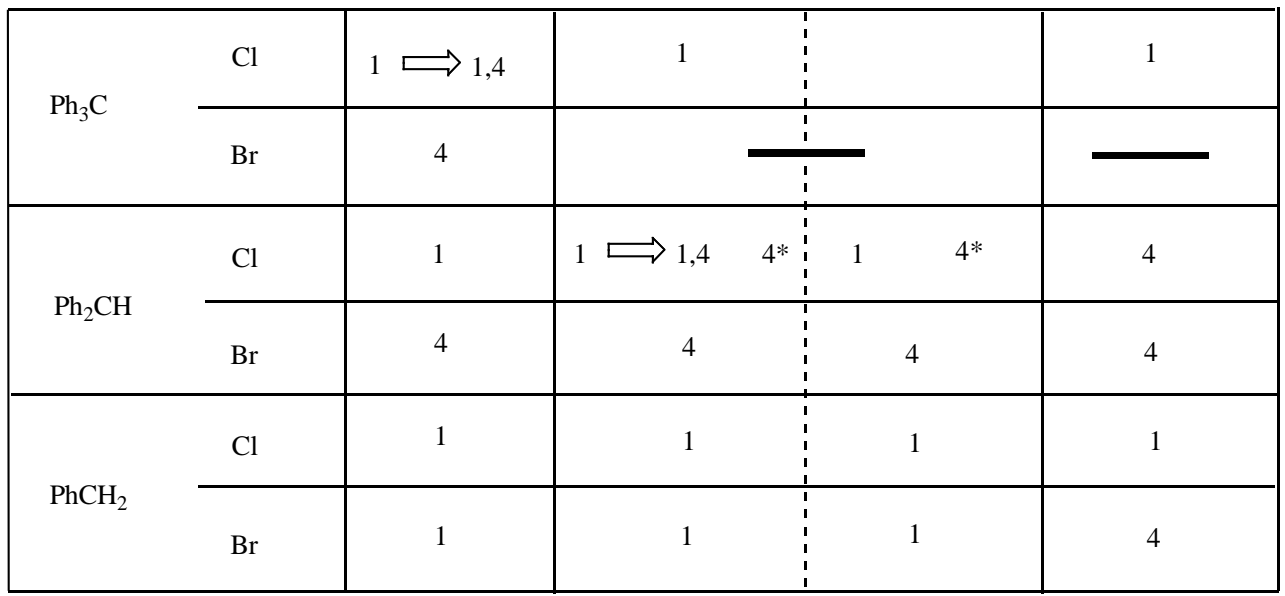

*Both tautomers

Fig. (5). Observed orientation pattern: 1 means N1-substituted, 4 means C4-substituted and 1,4 means 1,4-disubstituted pyrazoles.

internal solvent, $\mathrm{CDCl}_{3} 7.26$ for ${ }^{1} \mathrm{H}$ and 77.0 for ${ }^{13} \mathrm{C}$, DMSO$d_{6} 2.49$ for ${ }^{1} \mathrm{H}$ and 39.5 for ${ }^{13} \mathrm{C}$, and for ${ }^{15} \mathrm{~N}$ NMR nitromethane (0.00) was used as external standard. $2 \mathrm{D}\left({ }^{1} \mathrm{H}-{ }^{1} \mathrm{H}\right)$ gs-COSY and inverse proton detected heteronuclear shift correlation spectra, $\left({ }^{1} \mathrm{H}^{-13} \mathrm{C}\right)$ gs-HMQC, $\left({ }^{1} \mathrm{H}_{-}{ }^{13} \mathrm{C}\right)$ gs-HMBC and $\left({ }^{1} \mathrm{H}-{ }^{15} \mathrm{~N}\right)$ gs-HMBC, were acquired and processed using standard Bruker NMR software and in non-phase-sensitive mode [14].

\section{Microwave Experiments}

A mixture of the corresponding $N$-unsubstituted pyrazole 1-3 and the halogen derivatives in 1:1 or 2:1 molar ratios, at the $1.5 \mathrm{mmol}$ scale, was placed in an air-open tube ("Mini" \#7 Ace-Thred). The system was irradiated in a multimode microwave oven (Panasonic NN 5252 B) at different powers $(600 \mathrm{~W}$ and $900 \mathrm{~W})$ and times $(3 \mathrm{~min}, 5 \mathrm{~min}$ and $10 \mathrm{~min})$, the reaction occurring in semisolid/liquid state (Tables 1-3). After cooling to room temperature, the reaction crude was dissolved in dichloromethane and chromatographed over silica gel with $\mathrm{CH}_{2} \mathrm{Cl}_{2}$ and $\mathrm{CH}_{2} \mathrm{Cl}_{2}$-EtOH in different proportions of increasing polarity or ethyl ether-hexane as eluents.

\section{1-Trityl-1H-pyrazole (4a)}

$\mathrm{Mp}=198-202{ }^{\circ} \mathrm{C}$, (lit. [15], 202-204 ${ }^{\circ} \mathrm{C}$ ). $\mathrm{R}_{f}\left(\mathrm{CH}_{2} \mathrm{Cl}_{2}\right)$ : 0.27. $\mathrm{R}_{f}\left(\mathrm{CH}_{2} \mathrm{Cl}_{2}-\mathrm{EtOH} 9: 1\right): 0.83 .{ }^{1} \mathrm{H} \mathrm{NMR}$ and ${ }^{13} \mathrm{C} \mathrm{NMR}$ are described in references 11,15 and 16.

\section{1,4-Bis(trityl)-1H-pyrazole (5a)}

$\mathrm{Mp}=219-221^{\circ} \mathrm{C}\left(\mathrm{Cl}_{2} \mathrm{CH}_{2}\right.$-hexane $) . \mathrm{R}_{f}\left(\mathrm{CH}_{2} \mathrm{Cl}_{2}\right): 0.41 . \mathrm{R}_{f}$ $\left(\mathrm{CH}_{2} \mathrm{Cl}_{2}\right.$-EtOH 9:1): 0.87. $\delta_{\mathrm{H}}\left(\mathrm{CDCl}_{3}\right): 7.39\left(1 \mathrm{H}, \mathrm{d},{ }^{4} J_{3,5}=0.8\right.$ $\mathrm{Hz}, \mathrm{H} 3), 7.30-7.09\left(30 \mathrm{H}, \mathrm{m}, 6 \mathrm{C}_{6} \mathrm{H}_{5}\right), 7.06(1 \mathrm{H}, \mathrm{d}, \mathrm{H} 5) . \delta_{\mathrm{C}}$ $\left(\mathrm{CDCl}_{3}\right)$ : 147.0 (4-Ci), 143.1 (1-Ci), 141.2 (C3), 133.7 (C5), 130.2/130.0 (Co*), 128.1 (C4), 127.6/127.4 (Cm*), 126.1 $(\mathrm{Cp}), 78.5\left(1-\mathrm{Csp}^{3}\right), 57.9\left(4-\mathrm{Csp}^{3}\right) . \delta_{\mathrm{N}}\left(\mathrm{CDCl}_{3}\right):-158.3(\mathrm{~N} 1)$, -72.4 (N2). Anal. Calcd. for $\mathrm{C}_{41} \mathrm{H}_{32} \mathrm{~N}_{2}, \mathrm{M}=552$ : C, 89.10; $\mathrm{H}$, 5.84; N, 5.07. Found: C, 88.77; H, 5.71; N, 5.05.

\section{4-Trityl-1H-pyrazole (6a)}

It was not possible to isolate it as a pure compound and only the NMR data from a 1:1 mixture with 7 are given. $\delta_{\mathrm{H}}$ (DMSO- $\left.d_{6}\right): 7.28(\mathrm{~m}, \mathrm{H} m), 7.21$ (m, Hp and $\left.\mathrm{H} 3 / \mathrm{H} 5\right), 7.04$ $(\mathrm{m}, \mathrm{Ho}) . \delta_{\mathrm{C}}\left(\mathrm{DMSO}-d_{6}\right): 147.1\left({ }^{3} J={ }^{3} J=7.3, \mathrm{Ci}\right), 134.3$ (C3/C5, observed only by adding a drop of TFA), $129.7\left({ }^{1} J=\right.$ 156.7, Co $), 127.6\left({ }^{1} J=158.9,{ }^{3} J=7.8, C m\right), 126.1\left({ }^{1} J=\right.$ $\left.160.7,{ }^{3} J={ }^{3} J=7.3, \mathrm{Cp}\right), 123.2(\mathrm{C} 4), 57.4\left(\mathrm{Csp}^{3}\right)$.

\section{4-(9-phenyl-9H-fluoren-9-yl)-1H-pyrazole (7)}

$\mathrm{Mp}=230-232{ }^{\circ} \mathrm{C}$ (benzene). $\mathrm{R}_{f}\left(\mathrm{CH}_{2} \mathrm{Cl}_{2}\right): 0.01 . \mathrm{R}_{f}$ $\left(\mathrm{CH}_{2} \mathrm{Cl}_{2}\right.$-EtOH 9:1): 0.50. $\delta_{\mathrm{H}}\left(\mathrm{DMSO}-d_{6}\right): 7.90(2 \mathrm{H}$, ddd, ${ }^{3} J_{4^{\prime}, 3^{\prime}}=7.5 \mathrm{~Hz},{ }^{4} J_{4^{\prime}, 2^{\prime}}=1.2 \mathrm{~Hz},{ }^{5} J_{4^{\prime}, 1},=0.8 \mathrm{~Hz}, \mathrm{H} 4^{\prime} / \mathrm{H}^{\prime}$ '), $7.54(2 \mathrm{H}, \mathrm{s}, \mathrm{H} 3 / \mathrm{H} 5), 7.48\left(2 \mathrm{H}\right.$, ddd, ${ }^{3} J_{1^{\prime},{ }_{2}}=7.5 \mathrm{~Hz},{ }^{4} J_{1^{\prime}, 3},=$ $1.1 \mathrm{~Hz}, \mathrm{H} 1^{\prime} / \mathrm{H} 8$ '), 7.38 ( $2 \mathrm{H}, \mathrm{dt},{ }^{3} J_{3}, 2^{\prime}=7.5 \mathrm{~Hz}, \mathrm{H} 3$ ' $/ \mathrm{H}^{\prime}$ '), 7.31 (2H, dt, H2'/H7'), 7.22-7.16 (3H, m, Hm and $\mathrm{H} p), 6.99$ $(2 \mathrm{H}, \mathrm{m}, \mathrm{Ho}) . \delta_{\mathrm{C}}\left(\mathrm{DMSO}-d_{6}\right): 151.4\left({ }^{3} J={ }^{3} J=7.4, \mathrm{C} 8 \mathrm{a} / \mathrm{C} 9 \mathrm{a}\right)$, $145.5\left({ }^{3} J={ }^{3} J=7.2, \mathrm{Ci}\right), 139.1\left({ }^{3} J={ }^{3} J=6.8, \mathrm{C} 4 \mathrm{a} / \mathrm{C} 4 \mathrm{~b},\right)$, $132.7\left({ }^{1} J=185.8,{ }^{3} J=5.6, \mathrm{C} 3 / \mathrm{C} 5\right), 128.3\left({ }^{1} J=159.1,{ }^{3} J=\right.$ $7.0, \mathrm{Cm}), 127.8\left({ }^{1} J=161.5,{ }^{3} J=7.3, \mathrm{C} 2^{\prime} / \mathrm{C} 7{ }^{\prime}\right), 127.6\left({ }^{1} J=\right.$ $\left.159.8,{ }^{3} J=7.2, \mathrm{C}^{\prime} / \mathrm{C}^{\prime}{ }^{\prime}\right), 126.8\left({ }^{1} J=154.3, \mathrm{Co}\right), 126.5\left({ }^{1} J=\right.$ $\left.161.0,{ }^{3} J={ }^{3} J=7.6, C p\right), 125.5\left({ }^{1} J=160.5,{ }^{3} J=8.1\right.$, C1'/C8'), $123.7\left({ }^{2} J={ }^{2} J=8.5, \mathrm{C} 4\right), 120.4,\left({ }^{1} J=160.0,{ }^{3} J=\right.$ $\left.7.9, \mathrm{C}^{\prime} / \mathrm{C}^{\prime}\right), 57.5\left(\mathrm{C}^{\prime}\right) . \delta_{\mathrm{N}}\left(\mathrm{DMSO}^{\prime} d_{6}\right):-85.4(\mathrm{~N} 2)$; N1 could not be detected in the $\left({ }^{1} \mathrm{H}^{-15} \mathrm{~N}\right)$ gs-HMBC spectra. Exact Mass Calcd. for $\mathrm{C}_{22} \mathrm{H}_{17} \mathrm{~N}_{2}$ : 309.1392. Found: 309.1397.

\section{1-Benzhydryl-1H-pyrazole (4b)}

$\mathrm{Mp}=51.5-53{ }^{\circ} \mathrm{C}$ (chromatography) (lit. [15], 48-51 ${ }^{\circ} \mathrm{C}$ ). $\mathrm{R}_{f}\left(\mathrm{CH}_{2} \mathrm{Cl}_{2}\right): 0.19 . \mathrm{R}_{f}\left(\mathrm{CH}_{2} \mathrm{Cl}_{2}-\mathrm{EtOH} 9: 1\right): 0.78 .{ }^{13} \mathrm{C} \mathrm{NMR}$ is described in reference 16.

\section{4-Benzhydryl-1H-pyrazole (6b)}

$\mathrm{Mp}=176-178{ }^{\circ} \mathrm{C}(\mathrm{EtOH}) . \mathrm{R}_{f}\left(\mathrm{CH}_{2} \mathrm{Cl}_{2}\right): 0.03 . \mathrm{R}_{f}\left(\mathrm{CH}_{2} \mathrm{Cl}_{2-}\right.$ $\mathrm{EtOH} 9: 1): 0.45$. $\delta_{\mathrm{H}}\left(\mathrm{DMSO}-d_{6}\right): 12.66(1 \mathrm{H}, \mathrm{s}$ br, NH), 7.30- 
$7.25(6 \mathrm{H}, \mathrm{m}, \mathrm{H} m$ and $\mathrm{H} 3 / \mathrm{H} 5), 7.20-7.15(6 \mathrm{H}, \mathrm{m}, \mathrm{Ho}$ and $\mathrm{Hp}), 5.39(1 \mathrm{H}, \mathrm{s}, \mathrm{CH}) \cdot \delta_{\mathrm{H}}\left(\mathrm{CDCl}_{3}\right): 7.30-7.25(6 \mathrm{H}, \mathrm{m}, \mathrm{H} m$ and $\mathrm{H} 3 / \mathrm{H} 5), 7.21-7.17(6 \mathrm{H}, \mathrm{m}, \mathrm{H} o$ and $\mathrm{Hp}), 5.38(1 \mathrm{H}, \mathrm{s}$, $\mathrm{CH}) . \delta_{\mathrm{C}}\left(\mathrm{DMSO}-d_{6}\right): 144.8\left({ }^{3} J={ }^{3} J={ }^{2} J=7.3, \mathrm{Ci}\right), 138.4$ (vbr, C3/C5), $128.3\left({ }^{1} J=157.2, \mathrm{Co}\right), 128.2\left({ }^{1} J=160.3, \mathrm{Cm}\right)$, 126.0 ( $\left.{ }^{1} J=161.7,{ }^{3} J={ }^{3} J=7.2, C p\right), 122.7\left({ }^{2} J={ }^{2} J={ }^{2} J=\right.$ 8.6, C4), $46.7\left({ }^{1} J=127.2,{ }^{3} J={ }^{3} J=3.4, \mathrm{CH}\right) \cdot \delta_{\mathrm{C}}\left(\mathrm{CDCl}_{3}\right)$ : 144.2 (Ci), 133.7 (br, C3/C5), 128.7 (Co), 128.4 (Cm) 126.4 (Cp), $124.3(\mathrm{C} 4), 47.4(\mathrm{CH})$. Anal. Calcd. for $\mathrm{C}_{16} \mathrm{H}_{14} \mathrm{~N}_{2}, \mathrm{M}=$ 234: C, 82.02; H, 6.02; N, 11.96. Found: C, 81.76; H, 6.15; N 12.00 .

\section{1-Benzyl-1H-pyrazole (4c)}

It has been identified by ${ }^{1} \mathrm{H}-\mathrm{NMR}[15,17] . \mathrm{R}_{\mathrm{f}}\left(\mathrm{CH}_{2} \mathrm{Cl}_{2}\right)$ : 0.14. $\mathrm{R}_{\mathrm{f}}\left(\mathrm{CH}_{2} \mathrm{Cl}_{2}\right.$-EtOH 9:1): 0.70. ${ }^{13} \mathrm{C} \mathrm{NMR}$ is described in reference 18 .

\section{4-Benzyl-1H-pyrazole (6c)}

$\mathrm{Mp}=84-85^{\circ} \mathrm{C}\left(\mathrm{Cl}_{2} \mathrm{CH}_{2}\right.$-hexane) (lit. [19], 79-80 $\left.{ }^{\circ} \mathrm{C}\right)$.

\section{1-Trityl-3-methyl-1H-pyrazole $(8 a)$}

$\mathrm{Mp}=172.7-174.2{ }^{\circ} \mathrm{C}\left(\mathrm{Cl}_{2} \mathrm{CH}_{2}\right.$-hexane $) . \mathrm{R}_{f}\left(\mathrm{CH}_{2} \mathrm{Cl}_{2}\right)$ : 0.26. $\mathrm{R}_{f}\left(\mathrm{CH}_{2} \mathrm{Cl}_{2}-\mathrm{EtOH}\right.$ 9:1): 0.80. $\delta_{\mathrm{H}}\left(\mathrm{CDCl}_{3}\right): 7.31-7.27$ $(9 \mathrm{H}, \mathrm{m}, \mathrm{H} m$ and $\mathrm{Hp}), 7.20\left(1 \mathrm{H}, \mathrm{d},{ }^{3} J_{5,4}=2.4, \mathrm{H} 5\right), 7.18-7.16$ $(6 \mathrm{H}, \mathrm{m}, \mathrm{Ho}), 5.99(1 \mathrm{H}, \mathrm{d}, \mathrm{H} 4), 2.29\left(3 \mathrm{H}, \mathrm{s}, \mathrm{CH}_{3}\right) . \delta_{\mathrm{C}}$ $\left(\mathrm{CDCl}_{3}\right): 148.9(\mathrm{C} 3), 143.6(\mathrm{Ci}), 133.1\left({ }^{1} \mathrm{~J}=186.6,{ }^{2} \mathrm{~J}=10.1\right.$, C5), $130.1\left({ }^{1} J=157.6, \mathrm{Co}\right), 127.6\left({ }^{1} J=160.7, \mathrm{Cm}\right), 127.5$ $\left({ }^{1} J=160.6,{ }^{3} J={ }^{3} J=7.5, C p\right), 103.9\left({ }^{1} J=174.1,{ }^{2} J=11.1\right.$, $\left.{ }^{3} J_{\mathrm{CH} 3}=3.1, \mathrm{C} 4\right), 78.0(\mathrm{C}), 14.0\left({ }^{1} J=127.2, \mathrm{CH}_{3}\right) . \delta_{\mathrm{N}}(\mathrm{CD}-$ $\left.\mathrm{Cl}_{3}\right)$ : -160.4 (N1), -73.3 (N2). Anal. Calcd. for $\mathrm{C}_{23} \mathrm{H}_{20} \mathrm{~N}_{2}, \mathrm{M}$ = 324: C, 85.15; H 6.21; N 8.63. Found: C, 84.80; H 6.10; N 8.62 .

\section{1-Benzhydryl-3-methyl-1H-pyrazole $(8 b)$}

$\mathrm{Mp}=93.5-94.2{ }^{\circ} \mathrm{C}$ (ethyl ether-hexane). $\mathrm{R}_{f}\left(\mathrm{CH}_{2} \mathrm{Cl}_{2}\right)$ : 0.14. $\mathrm{R}_{f}\left(\mathrm{CH}_{2} \mathrm{Cl}_{2}-\mathrm{EtOH}\right.$ 9:1): 0.77. $\mathrm{R}_{f}$ (hexane-ethyl ether 7:3): 0.30. $\delta_{\mathrm{H}}\left(\mathrm{CDCl}_{3}\right): 7.36-7.29(6 \mathrm{H}, \mathrm{m}, \mathrm{H} m$ and $\mathrm{H} p), 7.09$ $\left(5 \mathrm{H}, \mathrm{m}, \mathrm{Ho}\right.$ and H5), $6.73(1 \mathrm{H}, \mathrm{s}, \mathrm{CH}), 6.04\left(1 \mathrm{H}, \mathrm{d},{ }^{3} J_{4,5}=\right.$ 2.3, H4), $2.30\left(3 \mathrm{H}, \mathrm{s}, \mathrm{CH}_{3}\right) . \delta_{\mathrm{C}}\left(\mathrm{CDCl}_{3}\right): 148.9$ (C3), 139.8 (Ci), $130.0\left({ }^{1} J=185.8,{ }^{2} J=9.2,{ }^{3} J_{\mathrm{CH}}=3.0, \mathrm{C} 5\right), 128.6\left({ }^{1} \mathrm{~J}=\right.$ $\left.159.3,{ }^{3} J=7.4, \mathrm{Cm}\right), 128.3\left({ }^{1} J=157.4, \mathrm{Co}\right), 127.9\left({ }^{1} J=\right.$ $\left.160.5,{ }^{3} J={ }^{3} J=7.5, \mathrm{C} p\right), 105.1\left({ }^{1} J=174.5,{ }^{2} J=8.3,{ }^{3} J_{\mathrm{CH} 3}=\right.$ 3.2, C4), $69.2\left({ }^{1} J=139.4,{ }^{3} J=3.2, \mathrm{CH}\right), 13.7\left({ }^{1} J=127.1\right.$, $\left.\mathrm{CH}_{3}\right) . \delta_{\mathrm{N}}\left(\mathrm{CDCl}_{3}\right):-166.1(\mathrm{~N} 1),-78.3(\mathrm{~N} 2)$. Anal. Calcd. for $\mathrm{C}_{17} \mathrm{H}_{16} \mathrm{~N}_{2}, \mathrm{M}=248$ : $\mathrm{C}, 82.22 ; \mathrm{H}, 6.49 ; \mathrm{N}, 11.28$. Found: $\mathrm{C}$, 82.10; H, 6.36; N, 11.33 .

\section{1-Benzhydryl-5-methyl-1H-pyrazole (9b)}

$\mathrm{Mp}=80.2-81.6{ }^{\circ} \mathrm{C}$ (ethyl ether-hexane). $\mathrm{R}_{f}\left(\mathrm{CH}_{2} \mathrm{Cl}_{2}\right)$ : 0.18. $\mathrm{R}_{f}$ (hexane-ethyl ether 7:3): 0.36. $\delta_{\mathrm{H}}\left(\mathrm{CDCl}_{3}\right): 7.35-7.27$ $(6 \mathrm{H}, \mathrm{m}, \mathrm{H} m$ and $\mathrm{Hp}), 7.15-7.12(4 \mathrm{H}, \mathrm{m}, \mathrm{Ho}), 7.48(1 \mathrm{H}, \mathrm{d}$, $\left.\mathrm{H} 3,{ }^{3} J_{3,4}=1.7\right), 6.59(1 \mathrm{H}, \mathrm{s}, \mathrm{CH}), 6.08\left(1 \mathrm{H}, \mathrm{dq}, \mathrm{H} 4,{ }^{4} J_{\mathrm{CH} 3}=\right.$ $0.7), 2.28\left(3 \mathrm{H}, \mathrm{d}, \mathrm{CH}_{3}\right) . \delta_{\mathrm{C}}\left(\mathrm{CDCl}_{3}\right): 139.7(\mathrm{Ci}), 138.8(\mathrm{C} 5)$, $138.8\left({ }^{1} J=184.5, \mathrm{C} 3\right), 128.4\left({ }^{1} J=161.6, \mathrm{C} o\right.$ and $\left.\mathrm{Cm}\right) 127.7$ $\left(\mathrm{C} p,{ }^{1} J=160.7,{ }^{3} J={ }^{3} J=7.4\right), 105.6\left({ }^{1} J=174.2, \mathrm{C} 4\right), 65.6$ $\left({ }^{1} J=135.3, \mathrm{CH}\right), 11.4\left({ }^{1} J=128.3, \mathrm{CH}_{3},\right) . \delta_{\mathrm{N}}\left(\mathrm{CDCl}_{3}\right):-$ 165.2 (N1), -78.9 (N2). Anal. Calcd for $\mathrm{C}_{17} \mathrm{H}_{16} \mathrm{~N}, \mathrm{M}=248$ : C, 82.22; H, 6.49; N, 11.28. Found: C, 81.77; H, 6.23; N, 11.25 .

\section{3-Methyl-1,4-bis(benzhydryl)-1H-pyrazole (10b)}

Oil. $\mathrm{R}_{f}\left(\mathrm{CH}_{2} \mathrm{Cl}_{2}\right)$ : 0.20. $\mathrm{R}_{f}$ (hexane-ethyl ether 7:3): 0.29. $\delta_{\mathrm{H}}\left(\mathrm{CDCl}_{3}\right):$ 7.34-7.07 $\left(20 \mathrm{H}, \mathrm{m}, 4 \mathrm{C}_{6} \mathrm{H}_{5}\right), 6.71(1 \mathrm{H}, \mathrm{s}, \mathrm{H} 5)$,
$6.62(1 \mathrm{H}, \mathrm{s}, 1-\mathrm{CH}), 5.27(1 \mathrm{H}, \mathrm{s}, 4-\mathrm{CH}), 2.00\left(3 \mathrm{H}, \mathrm{s}, \mathrm{CH}_{3}\right) . \delta_{\mathrm{C}}$ $\left(\mathrm{CDCl}_{3}\right): 147.3(\mathrm{C} 3), 143.7\left({ }^{3} J={ }^{3} J={ }^{2} J=7.3,4-\mathrm{C} i\right), 139.8$ $\left({ }^{3} J={ }^{3} J={ }^{2} J=6.8,1-\mathrm{Ci}\right), 129.9(\mathrm{C} 5), 128.7 / 128.5\left(\mathrm{Co} o^{*}\right)$, 128.3/128.2 (Cm*), 127.8/126.2 (Cp), 122.4 (C4), 69.2 $\left({ }^{1} J=138.8,1-\mathrm{CH}\right), 47.3\left({ }^{1} J=126.2,4-\mathrm{CH}\right), 12.4 \quad\left({ }^{1} \mathrm{~J}=127.2\right.$, $\left.\mathrm{CH}_{3},\right) . \delta_{\mathrm{N}}\left(\mathrm{CDCl}_{3}\right):-170.3(\mathrm{~N} 1),-78.3(\mathrm{~N} 2)$. Exact Mass Calcd. for $\mathrm{C}_{30} \mathrm{H}_{27} \mathrm{~N}_{2}$ : 415.2174. Found: 415.2170.

\section{3(5)-Methyl-4-benzhydryl-1H-pyrazole (11b)}

$\mathrm{Mp}=121-123{ }^{\circ} \mathrm{C}\left(\mathrm{Cl}_{2} \mathrm{CH}_{2}\right.$-hexane $) . \mathrm{R}_{\mathrm{f}}\left(\mathrm{CH}_{2} \mathrm{Cl}_{2}\right): 0.01 . \mathrm{R}_{\mathrm{f}}$ $\left(\mathrm{CH}_{2} \mathrm{Cl}_{2}\right.$-EtOH 9:1): 0.44. $\mathrm{R}_{\mathrm{f}}$ (hexane-ethyl ether 7:3): 0.03 . $\delta_{\mathrm{H}}\left(\mathrm{CDCl}_{3}\right): 7.28(4 \mathrm{H}, \mathrm{m}, \mathrm{Hm}), 7.21(2 \mathrm{H}, \mathrm{m}, \mathrm{Hp}), 7.15(4 \mathrm{H}$, m, Ho), 7.00 [1H, s, H5(H3)], $5.29(1 \mathrm{H}, \mathrm{s}, \mathrm{CH}), 2.04(3 \mathrm{H}, \mathrm{s}$, $\left.\mathrm{CH}_{3}\right) . \delta_{\mathrm{C}}\left(\mathrm{CDCl}_{3}\right): 143.7(\mathrm{Ci}), 142.2(\mathrm{br}, \mathrm{C} 3), 133.9$ (br, C5), $128.7\left({ }^{1} \mathrm{~J}=158.9, \mathrm{Co}\right), 128.3\left({ }^{1} \mathrm{~J}=158.9, \mathrm{Cm}\right), 126.3\left({ }^{1} \mathrm{~J}=\right.$ 163.0, Cp), 121.4 (C4), $47.1\left({ }^{1} \mathrm{~J}=125.4, \mathrm{CH}\right), 11.1\left({ }^{1} \mathrm{~J}=\right.$ 129.6, $\mathrm{CH}_{3}$ ). Anal. Calcd. for $\mathrm{C}_{17} \mathrm{H}_{16} \mathrm{~N}_{2}, \mathrm{M}=248$ : C, 82.22; H, 6.49; N, 11.28. Found: C, 81.63; H, 6.46; N, 11.02.

\section{1-Benzyl-3-methyl-1H-pyrazole (8c)}

It was obtained as an oil [20] in a 7:3 mixture 8c:9c. $\mathbf{R}_{f}$ (hexane-ethyl ether 7:3): 0.22. $\delta_{\mathrm{H}}\left(\mathrm{CDCl}_{3}\right)$ : 7.33-7.25 $(4 \mathrm{H}, \mathrm{m}$, $\mathrm{H} m, \mathrm{H} p$ and H5), $7.18(2 \mathrm{H}, \mathrm{m}, \mathrm{Ho}), 6.04\left(1 \mathrm{H}, \mathrm{dq},{ }^{3} J_{4,5}=2.3\right.$, $\left.{ }^{4} J_{\mathrm{CH} 3}=0.5, \mathrm{H} 4\right), 5.21\left(2 \mathrm{H}, \mathrm{s}, \mathrm{CH}_{2}\right), 2.30\left(3 \mathrm{H}, \mathrm{d}, \mathrm{CH}_{3}\right) . \delta_{\mathrm{C}}$ $\left(\mathrm{CDCl}_{3}\right): 148.5(\mathrm{C} 3), 136.7(\mathrm{Ci}), 129.8(\mathrm{C} 5), 128.5(\mathrm{Cm})$, $\left.127.7(\mathrm{Cp}), 127.3(\mathrm{Co}), 55.4\left(\mathrm{CH}_{2}\right), 13.4\left(\mathrm{CH}_{3}\right)\right) . \delta_{\mathrm{N}}(\mathrm{CD}-$ $\left.\mathrm{Cl}_{3}\right):-174.5(\mathrm{~N} 1),-79.3(\mathrm{~N} 2)$.

\section{1-Benzyl-5-methyl-1H-pyrazole (9c)}

It was obtained as an oil $[20,21]$ in a 3:7 mixture $\mathbf{9 c : 8 c} . \mathbf{R}_{f}$ (hexane-ethyl ether 7:3): 0.41. $\delta_{\mathrm{H}}\left(\mathrm{CDCl}_{3}\right): 7.45(1 \mathrm{H}, \mathrm{d}$, $\left.{ }^{3} J_{3,4}=1.9, \mathrm{H} 3\right), 7.25-7.33(3 \mathrm{H}, \mathrm{m}, \mathrm{H} m$ and $\mathrm{H} p), 7.08(2 \mathrm{H}, \mathrm{m}$, $\mathrm{Ho}), 6.05\left(1 \mathrm{H}, \mathrm{dq},{ }^{4} J_{\mathrm{CH} 3}=0.8, \mathrm{H} 4\right), 5.27\left(2 \mathrm{H}, \mathrm{s}, \mathrm{CH}_{2}\right), 2.18$ $\left(3 \mathrm{H}, \mathrm{d}, \mathrm{CH}_{3}\right) . \delta_{\mathrm{C}}\left(\mathrm{CDCl}_{3}\right): 138.4(\mathrm{C} 3), 138.1(\mathrm{C} 5), 136.9(\mathrm{Ci})$, $128.5(\mathrm{Cm}), 127.7(\mathrm{Cp}), 126.5(\mathrm{Co}), 105.6(\mathrm{C} 4), 52.7\left(\mathrm{CH}_{2}\right)$, $10.9\left(\mathrm{CH}_{3}\right) . \delta_{\mathrm{N}}\left(\mathrm{CDCl}_{3}\right):-172.1(\mathrm{~N} 1),-77.2(\mathrm{~N} 2)$.

\section{1-Trityl-3,5-dimethyl-1H-pyrazole (12a)}

$\mathrm{Mp}=204{ }^{\circ} \mathrm{C}\left(\mathrm{Cl}_{2} \mathrm{CH}_{2}\right.$-hexane $) . \mathrm{R}_{f}\left(\mathrm{CH}_{2} \mathrm{Cl}_{2}\right): 0.21 . \mathrm{R}_{f}$ $\left(\mathrm{CH}_{2} \mathrm{Cl}_{2}\right.$-EtOH 9:1): 0.82. $\delta_{\mathrm{H}}\left(\mathrm{CDCl}_{3}\right): 7.35-7.27(9 \mathrm{H}, \mathrm{m}$, $\mathrm{H} m$ and $\mathrm{Hp}), 7.16(6 \mathrm{H}, \mathrm{m}, \mathrm{Ho}), 5.92(1 \mathrm{H}, \mathrm{s}, \mathrm{H} 4), 2.21(3 \mathrm{H}, \mathrm{s}$, $\left.\mathrm{CH}_{3}-3\right), 1.48\left(3 \mathrm{H}, \mathrm{s}, \mathrm{CH}_{3}-5\right) \cdot \delta_{\mathrm{C}}\left(\mathrm{CDCl}_{3}\right): 145.5(\mathrm{C} 3), 143.5$ (Ci), 141.8 (C5), 130.7 (Co, $\left.{ }^{1} J=160.2,{ }^{3} J={ }^{3} J=6.2\right), 127.9$ $\left(\mathrm{Cm},{ }^{1} J=160.6,{ }^{3} J=7.2\right), 127.1\left(\mathrm{Cp},{ }^{1} \mathrm{~J}=160.7,{ }^{3} \mathrm{~J}={ }^{3} J=\right.$ 7.6), $108.0\left(\mathrm{C} 4,{ }^{1} J=171.5\right), 14.4\left(\mathrm{CH}_{3}-5,{ }^{1} J=128.4\right), 14.0$ $\left(\mathrm{CH}_{3}-3,{ }^{1} J=126.7\right) . \delta_{\mathrm{N}}\left(\mathrm{CDCl}_{3}\right):-165.8(\mathrm{~N} 1),-73.3(\mathrm{~N} 2)$. Anal. Calcd. for $\mathrm{C}_{24} \mathrm{H}_{22} \mathrm{~N}_{2}, \mathrm{M}=338: \mathrm{C}, 85.17 ; \mathrm{H}, 6.55 ; \mathrm{N}$, 8.28. Found: C, 84.79; H, 6.37; N, 8.25.

\section{4-Benzhydryl-3,5-dimethyl-1H-pyrazole $(13 \mathrm{~b})$}

$\mathrm{Mp}=158-159^{\circ} \mathrm{C}\left(\mathrm{Cl}_{2} \mathrm{CH}_{2}\right.$-hexane $) . \mathrm{R}_{\mathrm{f}}\left(\mathrm{CH}_{2} \mathrm{Cl}_{2}\right): 0.01 . \mathrm{R}_{\mathrm{f}}$ $\left(\mathrm{CH}_{2} \mathrm{Cl}_{2}-\mathrm{EtOH}\right.$ 9:1): 0.44. $\delta_{\mathrm{H}}\left(\mathrm{DMSO}-\mathrm{d}_{6}\right): 11.99(\mathrm{~s}, 1 \mathrm{H}$, $\mathrm{NH}), 7.28$ (m, 4H, Hm), 7.19 (m, 2H, Hp), 7.04 (m, 4H, Ho), $5.42(\mathrm{~s}, 1 \mathrm{H}, \mathrm{CH}), 1.76\left(\mathrm{~s}, 6 \mathrm{H}, 2 \times \mathrm{CH}_{3}\right) . \delta_{\mathrm{C}}\left(\mathrm{CDCl}_{3}\right): 145.9$ (C3), $143.3\left(\mathrm{Ci},{ }^{3} J={ }^{3} J={ }^{2} J=7.6\right), 135.9$ (C5), $128.7\left(\mathrm{Co},{ }^{1} J\right.$ $=156.3), 128.1\left(\mathrm{Cm},{ }^{1} J=158.5,{ }^{3} J=7.7\right), 126.0\left(\mathrm{Cp},{ }^{1} J=\right.$ $\left.160.5,{ }^{3} J={ }^{3} J=7.5\right), 116.5(\mathrm{C} 4), 45.8\left(\mathrm{CH},{ }^{1} J=126.0\right), 12.6$ $\left(\mathrm{CH}_{3}-3\right), 9.8\left(\mathrm{CH}_{3}-5\right)$. Anal. Calcd. for $\mathrm{C}_{18} \mathrm{H}_{18} \mathrm{~N}_{2}, \mathrm{M}=262$ : C, 82.41; H, 6.92; N, 10.68. Found: C, 81.99; H, 6.59; N, 10.74 .

\section{1-benzyl-3,5-dimethyl-1H-pyrazole (12c)}

Oil (lit.[22,23], bp 139-141 $\left.{ }^{\circ} \mathrm{C} / 760 \mathrm{~mm}\right) . \mathrm{R}_{f}\left(\mathrm{CH}_{2} \mathrm{Cl}_{2}\right)$ : 0.12. $\mathrm{R}_{f}\left(\mathrm{CH}_{2} \mathrm{Cl}_{2}\right.$-EtOH 9:1): 0.73. 


\section{4-benzyl-3,5-dimethyl-1H-pyrazole (13c)}

$\mathrm{Mp}=142-144{ }^{\circ} \mathrm{C}\left(\mathrm{Cl}_{2} \mathrm{CH}_{2}\right.$-hexane) (lit. [23], $\left.148{ }^{\circ} \mathrm{C}\right) . \mathrm{R}_{f}$ $\left(\mathrm{CH}_{2} \mathrm{Cl}_{2}\right): 0.01 . \mathrm{R}_{f}\left(\mathrm{CH}_{2} \mathrm{Cl}_{2}\right.$-EtOH 9:1): 0.37.

\section{ACKNOWLEDGEMENTS}

This work was financed by DGES/MCyT (Projects BQU2003-00976 and CTQ2006-02586). One of us (M. M. Blanco) thanks to Fundación Carolina and the Ministerio de Educación, Ciencia y Tecnología of Argentina for a grant during her stay in Spain.

\section{REFERENCES}

[1] Elguero, J.; Goya, P.; Jagerovic, N.; Silva, A. M. S. In Targets in Heterocyclic Systems, Attanasi, O. A.; Spinelli, D. Eds, Italian Society of Chemistry, Roma, Italy, 2002, Vol. 6, pp. 52-98.

[2] Bekhit, A. A.; Ashour, H. M.; Guemei, A. A. Arch. Pharm. (Weinheim), 2005, 338, 167.

[3] Stanovnik, B.; Svete, J. In Science of Synthesis: Houben-Weyl Methods of Molecular Transformations, Neier, R. Ed., Thieme Medical Publishers, Stuttgart, Germany, 2002, Vol. 12, pp. 15-225.

[4] McHardy, S. F.; Vetelino, M. G. U.S. Patent 6,960,609 to Pfizer, Inc. November 1, 2005.

[5] Cabildo, P.; Claramunt, R. M.; Forfar, I.; Elguero, J. Tetrahedron Lett., 1994, 35, 183

[6] Cabildo, P.; Claramunt, R. M.; Forfar, I.; Foces-Foces, C.; LlamasSaiz, A. L.; Elguero, J. Heterocycles, 1994, 37, 1623.

[7] Forfar, I.; Cabildo, P.; Claramunt, R. M.; Elguero, J. Chem. Lett., 1994, 2079.

[8] Almena, I.; Díez-Barra, E.; de la Hoz, A.; Ruíz, J.; SánchezMigallón, A.; Elguero, J. J. Heterocycl. Chem., 1998, 35, 1263.
[9] Kalinoswski, H.-O.; Berger, S.; Braun, S. In Carbon-13 NMR Spectroscopy, John Wiley \& Sons, New York, 1988, pp. 157.

[10] Powers, D. R.; Boeltz, B. R.; Drahl, M. A. American Chemical Society, Division of Chemical Education, $231^{\text {st }}$ ACS National Meeting, Atlanta, GA, March 26-30, 2006, Communication 517; Strohl, K. C.; Powers, D. R. American Chemical Society, Division of Chemical Education, 233 ${ }^{\text {st }}$ ACS National Meeting, Chicago, IL, March 26-31, 2007, Communication 578.

[11] Begtrup, M.; Boyer, G.; Cabildo, P.; Cativiela, C.; Claramunt, R. M.; Elguero, J.; García, J. I.; Toiron, C.; Vedso, P. Magn. Reson. Chem., 1993, 31, 107.

[12] Claramunt, R. M.; Sanz, D.; López, C.; Jiménez, J. A.; Jimeno, M. L.; Elguero, J.; Fruchier, A. Magn. Reson. Chem., 1997, 35, 35.

[13] Sanz, D.; Claramunt, R. M.; Glaser, J.; Trofimenko, S.; Elguero, J. Magn. Reson. Chem., 1996, 34, 843.

[14] Berger, S.; Braun, S. 200 and more NMR Experiments, Wiley$\mathrm{VCH}$, Weinheim, Germany, 2004.

[15] Claramunt, R. M.; Elguero, J.; Garcerán, R. Heterocycles, 1985, $23,2895$.

[16] Elguero, J.; Claramunt, R. M.; Garcerán, R.; Julià, S.; Avila, L.; del Mazo, J. M. Magn. Reson. Chem., 1987, 25, 260.

[17] Dou, H. J. M.; Elguero, J.; Espada, M.; Hassanaly, P. An. Quim., 1978, 74, 1137.

[18] Claramunt, R. M.; Sanz, D.; Santa María, M. D.; Jimenez, J. A.; Jimeno, M. L.; Elguero, J. Heterocycles, 1998, 47, 301.

[19] Echevarria, A.; Elguero, J. Synth. Commun., 1993, 23, 925.

[20] Tarragó, G.; Ramdani, A.; Elguero, J.; Espada, M. J. Heterocycl. Chem., 1980, 17, 137.

[21] Salazar, L.; Espada, M.; Avendaño, C.; Claramunt, R. M.; Sanz, D.; Elguero, J. J. Org. Chem., 1992, 57, 1563.

[22] Grandberg, I. I.; Khim. Geterotsikl. Soedin., 1965, 1, 279. CA 63: 8339-8340.

[23] Grandberg, I. I; Kost, A. N. Zh. Obshch. Khim., 1960, 30, 2942. CA 55: $16519 \mathrm{e}$. 